\title{
ANALYSIS OF ELECTROMAGNETIC INFLUENCE ON STEEL PIPELINES FROM THE ELEMENTS OF ELECTRIC POWER SYSTEM*
}

\author{
Blagoja Markovski, Leonid Grčev \\ Faculty of Electrical Engineering and Information Technologies, \\ "Ss. Cyril and Methodius" University in Skopje, \\ Rugjer Bošković bb, P.O. box 574, 1001 Skopje, Republic of Macedonia \\ bmarkovski@feit.ukim.edu.mk
}

\begin{abstract}
A b s t r a c t: Power transmission lines often share same corridors with steel pipelines for oil and gas. When phase to ground fault occurs, high voltages may appear on the pipelines due to different mechanisms of mutual coupling. These voltages propagate at long distances from the fault location, and may pose a serious threat for the safety of the personnel and integrity of the pipeline. To provide adequate protection, calculation of the mutual coupling is required during the design stage of systems. Induced voltages are strongly influenced by the disposition of the both systems, their configuration and characteristics, elements that mutually interact etc. In this paper, we analyze induced voltages on practical pipeline system. Parametric analysis will show how far interventions on both systems can influence the induced voltages.
\end{abstract}

Key words: electromagnetic influence; gas; oil; pipelines; safety

\section{АНАЛИЗА НА ЕЛЕКТРОМАГНЕТНИТЕ ВЛИЈАНИЈА ОД ЕЛЕМЕНТИ НА ЕЛЕКТРОЕНЕРГЕТСКИОТ СИСТЕМ ВРЗ ЧЕЛИЧНИТЕ ЦЕВКОВОДИ}

А п с т р а к т: Цевководните системи за нафта и гас честопати влегуваат во зоната на влијание од елементи на електроенергетскиот систем. Во случај на доземен спој на енергетски вод можат да се индуцираат високи напони на цевководот како резултат на различни механизми на меѓусебна интеракција. Поради добрата електрична изолација на цевководите, овие напони се простираат на голема оддалеченост од местото на доземен спој, а можат да резултираат со електричен удар врз луѓето кои се во контакт со достапни делови на цевководот, да предизвикаат оштетување на приклучената електрична опрема и нарушување на интегритетот на цевководот. Со цел да се обезбедат соодветни заштитни мерки, неопходна е анализа на меѓусебните влијанија уште во фазата на проектирање на овие системи. Индуцираните напони во голема мера зависат од диспозицијата на двата система, нивната конфигурација и карактеристики, од меѓусебната интеракција на елементите од двата система итн. Во овој труд е извршена анализа на индуцирани напони на цевковод базирана на практична ситуација. Преку симулација се покажа во колкава мера промените во конфигурацијата на двата система влијаат врз индуцираните напони.

Клучни зборови: електромагнетни влијанија; гас; нафта; цевковод, безбедност

\section{INTRODUCTION}

The increasing number and density of electric power transmission lines and steel pipelines, results with frequent approaching or crossing of these systems and their mutual interaction. This interaction may have negative consequences on the integrity and safety of both systems, as a result of corrosive influences or electromagnetic induction. Coupling mechanisms of the elements of electric power system with underground steel pipelines can be divided to inductive and conductive [1], [2].

\footnotetext{
* Extended version of the manuscript published in the Proceedings of the $10^{\text {th }}$ MAKO CIGRE Conference, Ohrid, September 24-26, 2017 (Проширена верзија од трудот објавен во Зборникот на трудови од 10. Советување на МАКО СИГРЕ, Охрид, 24-26 септември 2017).
} 
Inductive coupling is related to the AC magnetic field generated by electric power transmission lines that interacts with the steel pipe, inducing electromotive forces on the pipe in the zones of influence. Magnitude of induced voltages due to inductive coupling depends on the currents, the length of parallelism and distance between electric power transmission line and pipeline. In most severe case of earth fault in system with solidly earthed neutral, voltages between pipeline and surrounding earth can reach magnitudes of several kilovolts. Several tens of volts can also be induced in steady state conditions as result of the geometrical asymmetry of phase conductors with respect to the pipeline.

Fault currents discharged through grounded structures, such as grounding systems of electric substations, tower grounding electrodes or earth continuity conductors, are source of ground potential rise (GPR) in their surroundings. Dangerous voltages between the pipe steel and surrounding earth may appear when coated steel pipeline, with potential of reference earth, is passing through zones of high GPR [3].

Individual influence from one of the coupling mechanisms, in absence of the others, may be analyzed using simple models. But when pipeline is subjected to simultaneous influence from different coupling mechanisms, which is the most common case, safety analysis becomes very extensive and complex. Induced potentials from different sources are variable by intensity and phase along the pipeline, and strongly depend on the fault location and distribution of fault currents the electric power system. Therefore safety analyses require simultaneous consideration of all coupling mechanisms, for different fault locations, and from all elements of the electric power transmission system that interact with the pipeline.
This paper analyzes electromagnetic induction on underground steel pipeline from faulted electric transmission line. Strong simultaneous influence from conductive and inductive coupling mechanisms results with induced voltages between the pipe and surrounding earth, so called coating stress voltages, in order of few $\mathrm{kV}$. Safety limits for protection of the coating, connected equipment and people that may be in contact with exposed metallic parts are significantly exceeded.

Software developed by the authors, enables to analyze the simultaneous influences, to identify most significant sources of influence and locations with hazardous induced voltages on the pipeline, and analyze the effects of many possible interventions on both systems in order to reduce induced voltages within safe limits.

\section{DESCRIPTION OF THE ANALYZED SYSTEM}

Figure 1 illustrates the elements of the power system that interact with the pipeline. Two $110 \mathrm{kV}$ cables, as part of the combined cable-overhead lines that connect substation $\mathrm{S} 1$ with substations $\mathrm{S} 2$ and S3, run parallel to the analyzed pipeline for a distance of $4 \mathrm{~km}$. The clearance between both systems varies between 2 and $10 \mathrm{~m}$. Copper earth continuity conductor is buried between the cables, with one end bonded to the grounding of substation S1 and with the other bonded to the grounding at the transition station, where cable lines continue to double system overhead line. The double system overhead line runs parallel to the pipeline for a distance of 2 $\mathrm{km}$, with mutual clearance that varies between 20 and $200 \mathrm{~m}$.

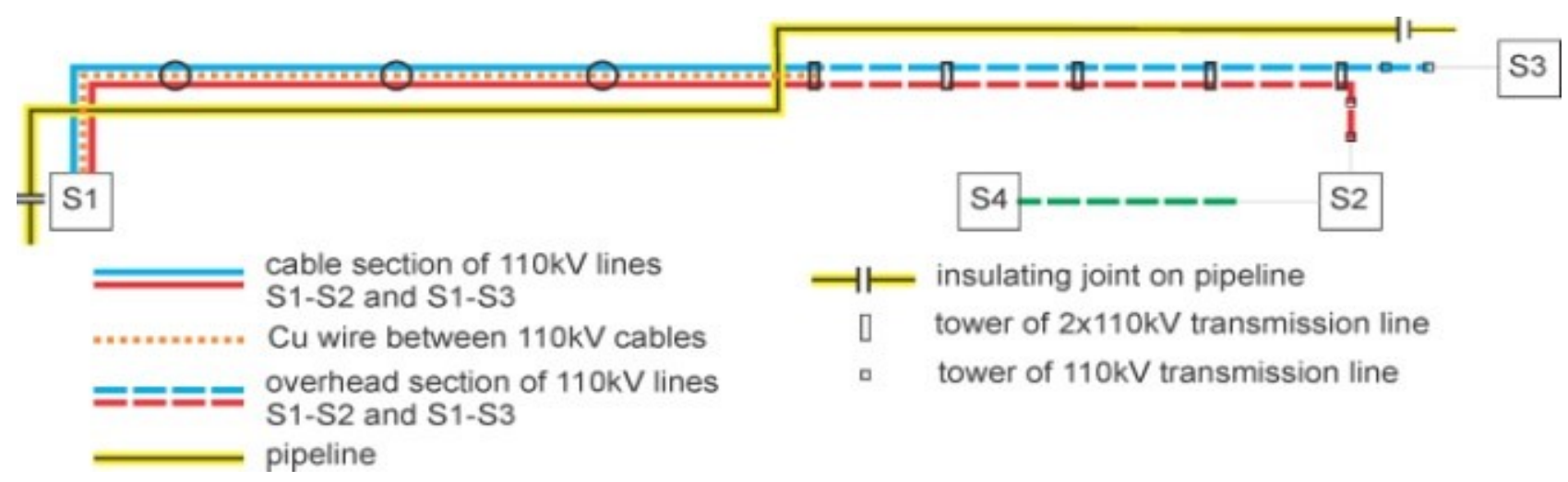

Fig. 1. Elements of the power system that interact with the pipeline 
Pipeline is subjected to inductive influences from the combined $110 \mathrm{kV}$ lines S1-S2, S1-S3, overhead line S2-S4 and to the conductive influences from the grounding system of the electrical substation S1, copper earth continuity conductor and tower grounding electrodes of HV transmission line. The analyzed pipeline section is electrically separated from the rest of the pipeline system by insulating joints on both ends, to prevent transfer of induced voltages.

\section{MODEL DESCRIPTION}

Induced voltages are analyzed with software developed by the authors. The software incorporates complex model that requires precise description of all elements of the power system acting as source of influences, and the pipeline under consideration. Both systems are modeled by equivalent electric circuits that simultaneously consider all coupling mechanisms.

Conductors are divided into large number of short segments with constant characteristics, expressed by their longitudinal impedances and shunt admittances. Mutual inductive coupling is expressed by longitudinal induced electromotive forces (EMF) and ground potential rise through transversal EMF, using exact electromagnetic method [4]. Rigorous evaluation of longitudinal impedance and transversal admittance, involves numerical solution of infinite integrals that require large computer resources. To improve the computational efficiency in analysis of large systems, interpolation in pre-computed tables with discrete number of solutions of the infinite integrals is used.
The equivalent electric circuits and their elements are calculated following the theory provided by [4]-[6], and the model is verified by comparison with other models based in electromagnetic theory [7], transmission line theory [8] и and published results from theoretical and practical studies.

In analysis of earth fault on electric power transmission line, the model calculates fault current distribution in all elements of the power system that are considered as sources of influence. Currents in the phase conductors, screening conductors and earth wires are basis for further analysis of inductive coupling, while the fault currents discharged to ground through grounded structures are basis for further analysis of conductive coupling.

As illustrated on Figure 2, although earth fault appears on the line connecting S1 and S2, the influences of the other lines that interact with the pipeline must also be considered. Depending on the disposition of the systems, influences of the other transmission lines may be significant, as in the case of the line connecting S1 and S3 that shares the same corridor with the faulted line connecting S1 and S2 and carries significant portion of the fault current, or insignificant influence as in the case of the distant transmission line connecting S2 and S4. Depending on the fault location, the influence of the other lines on the pipeline may be reductive $\left(I_{s 3}\right.$ and $I_{k v s 1}$ have opposite direction left from the fault location and portion of the magnetic field is cancelled) or additive $\left(I_{\mathrm{s} 3}\right.$ and $I_{\mathrm{kvs} 1}$ have same direction right from the fault location and the corresponding magnetic fields add up).
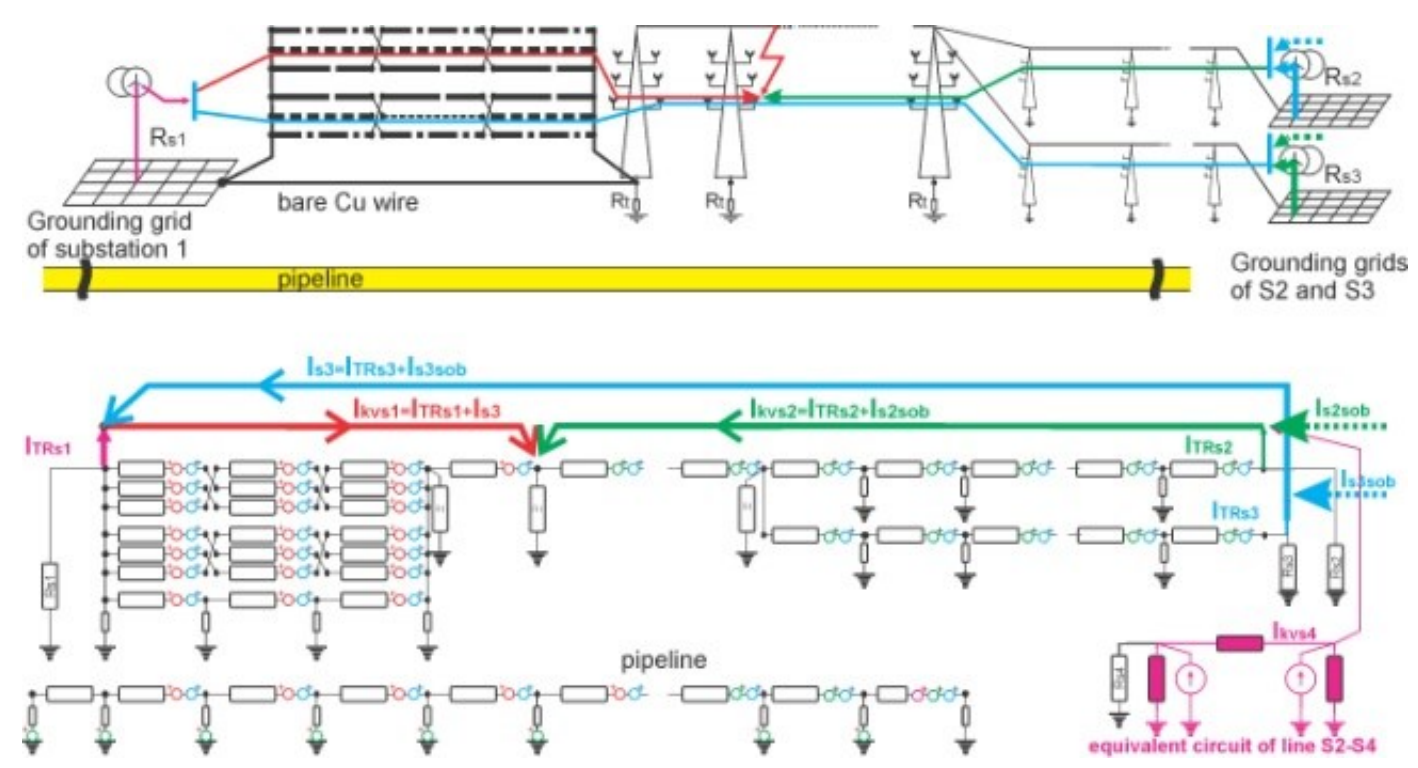

Fig. 2. Equivalent electric circuit of the elements of the electric power system and the pipeline 


\section{RESULTS FROM CASE STUDY}

\section{Analysis of the projected system}

The first step of the safety analysis is to calculate the maximum possible induced voltages on the pipeline that is at design stage, from existing elements of the electric power system. At this stage, safety measures are not considered. Maximum voltages that may appear between the pipe and surrounding earth are provided in Figure 3. These voltages represent the coating stress voltages, voltages applied to connected electronic equipment on the pipeline, and touch voltages for people in contact with exposed metallic parts of the pipeline, in most severe situation of earth fault on the electric power system. Maximum ground potentials along the pipeline are also provided. In the most severe situation, maximum voltage between the pipe and surrounding earth is $3.7 \mathrm{kV}$. According to [9], the maximum coating stress voltage for standard insulation of the pipe is $2 \mathrm{kV}$. This voltage is well exceeded for a distance of $1.5 \mathrm{~km}$ which is one-third of the pipeline length. According to [10], coating stress voltages in the range $3-5 \mathrm{kV}$ may cause arcing through coating defects and may permanently damage the pipe or the connected equipment.

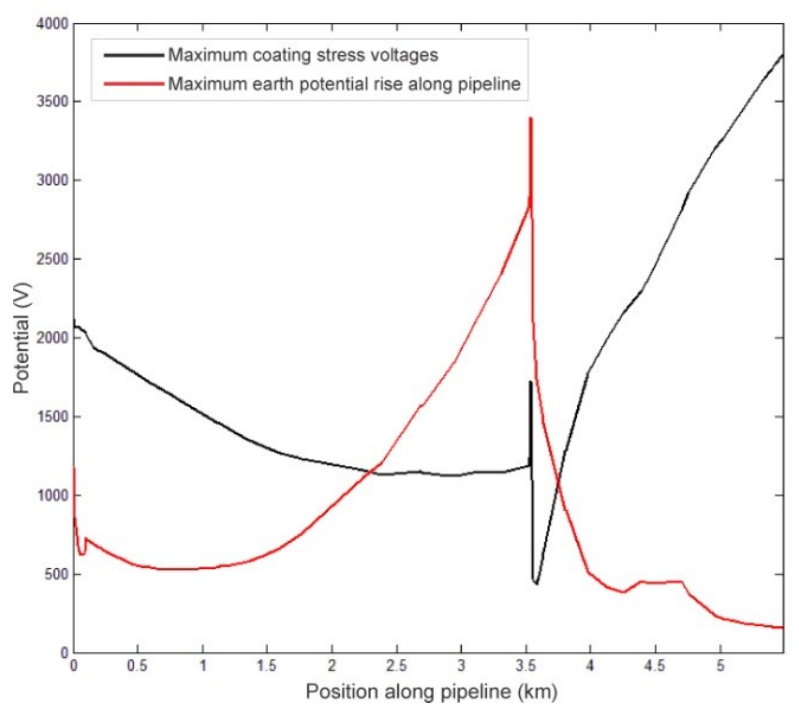

Fig. 3. Maximum coating stress voltage and ground potential rise

The software enables to identify the most severe fault location. According to Figure 4, it is located at distance of $3.75 \mathrm{~km}$ from the beginning of the line connecting S1 and S2, at the transition station from cable-to-overhead transmission line. The software also data provides the fault current distribution in all screening conductors and earthwires, as illustrated on Figure 4, thus enabling to identify the fault current paths and the influence from these elements of the power system. It is important to note that the maximum voltages on the pipeline occur at distance of $3 \mathrm{~km}$ from the fault location, as illustrated on Figure 5.

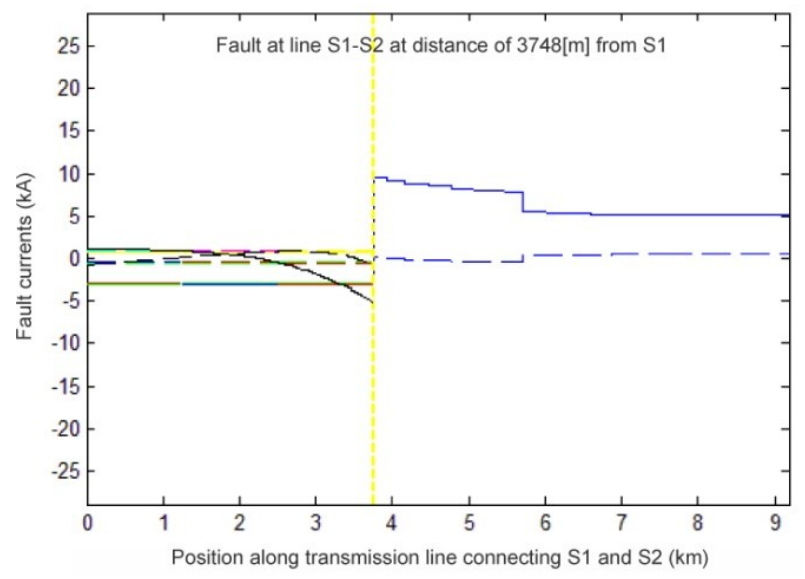

Fig. 4. Fault current distribution in elements of the electric power system (full line - real value, dashed line - imaginary value)

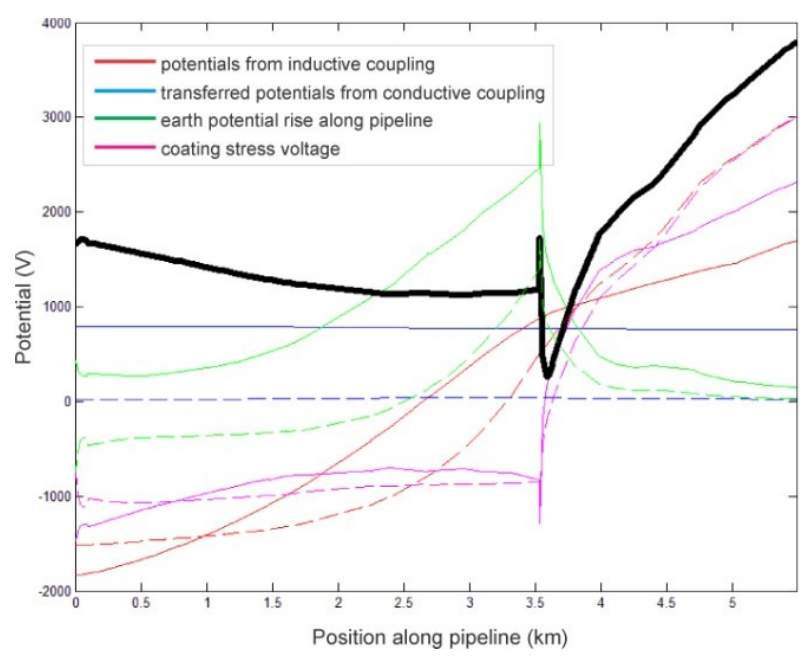

Fig. 5. Distribution of induced potentials along pipeline (full line - real value, dashed line - imaginary value)

Also it is possible to identify the influence of different groups of elements of the power system. Figure 6 provides the induced potentials as result of inductive coupling, transferred potentials on the pipe as result of conductive coupling, ground potentials along the pipeline, and the cumulative effects from all coupling mechanisms. All potentials are provided as complex values, by their real and imaginary part, to have better insight of their additive or reductive effects. 


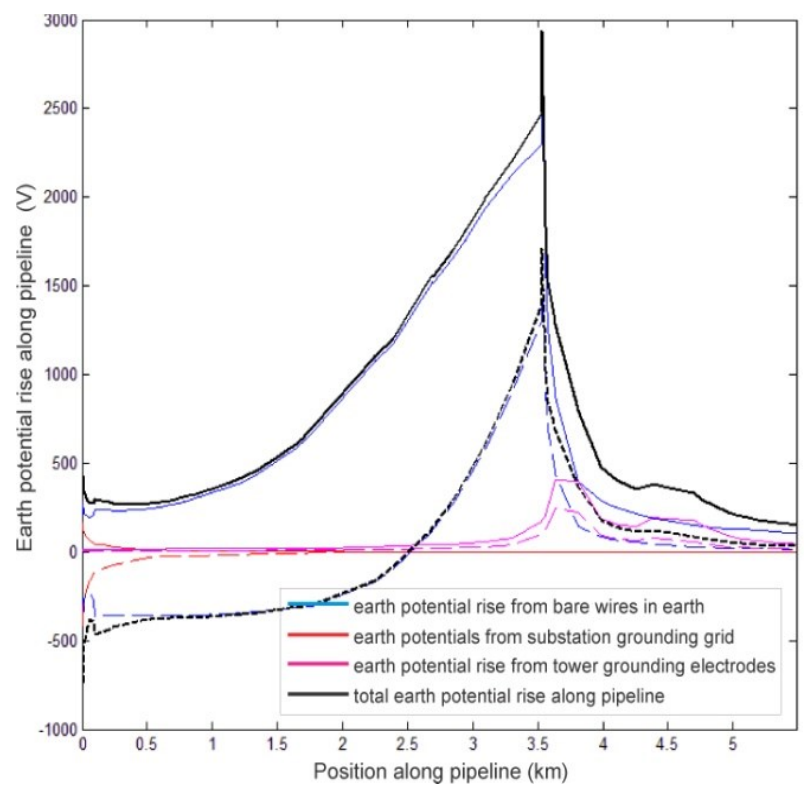

Fig. 6. Potentials from grounded structures of the electric power system

(full line - real value, dashed line - imaginary value)

Entire length of the pipeline is subjected to simultaneous cumulative influence from intense inductive and conductive coupling. Induced potentials due to inductive coupling have their maximum values at the ends of the pipeline, while high GPR can be observed around the middle of the pipeline, near the transition station from cable-to-overhead line. The copper earth continuity conductor is identified as most significant source of high GPR.

Identification of most significant sources of influence may provide guidance on the selection of safety measures to reduce the induced voltages within safe levels. Reduction of the high GPR can be achieved only by intervention on the existing power transmission line, while to reduce the effects of the inductive coupling, several interventions will be considered on the pipeline.

The problem with high GPR at the transition station of cable-overhead transmission line is well known [11]. Large portion of the fault current is returned through the cable sheaths due to their strong inductive coupling with the phase conductors, and is discharged into the earth through the ground connections at the transition station. In the analyzed case, significant portion of the fault current is discharged through the bare copper earth continuity conductor that is connected with the cable sheaths and earthwires at the transition station. The high earth potentials are result of the small clearance between the copper conductor and the pipe, which is around $2.5 \mathrm{~m}$, and their long parallelism at distance of around $3.5 \mathrm{~km}$. Since the copper conductor is identified as major source of high GPR, the aim of the first intervention is to reduce the GPR within safe levels.

\section{RESULTS FROM THE FIRST INTERVENTION - REDUCTION OF THE HIGH GROUND POTENTIALS}

In this section we analyze the effects of disconnection of the copper wire from the ground connection at the transition station, as possible intervention to reduce the high ground potentials. Results of this intervention are illustrated on Figures 7 to 10. The maximum ground potentials are reduced twice, and they are within safe levels for the insulation of the pipeline and the connected equipment. But this disconnection results with increase of the inductive coupling and the ground potentials around the substation S1. As result, induced potentials on the left side of the pipeline are increased to about $30 \%$ compared with the previous case. The induced potentials on the right side of the pipeline, solely as result of the inductive coupling with the overhead transmission line, remain unchanged.

Results indicate that voltages between the pipe and surrounding soil still exceed the safe levels at large portion of the pipeline. Therefore additional interventions are $r$ equired to reduce the inductive coupling from the transmission line, as a dominant source of induced voltages.

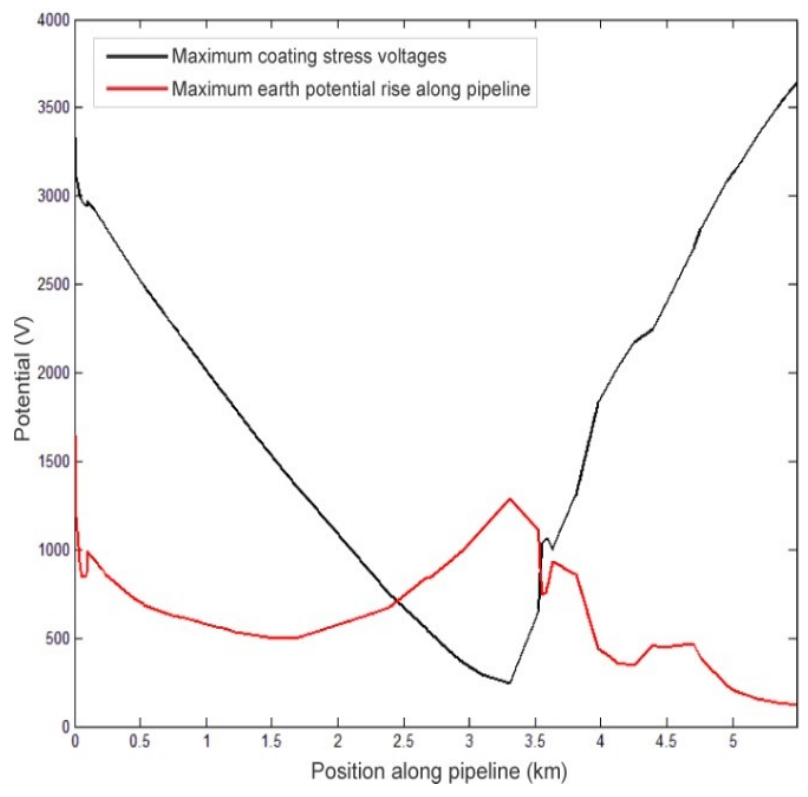

Fig. 7. Maximum coating stress voltage and ground potential rise after the first intervention 


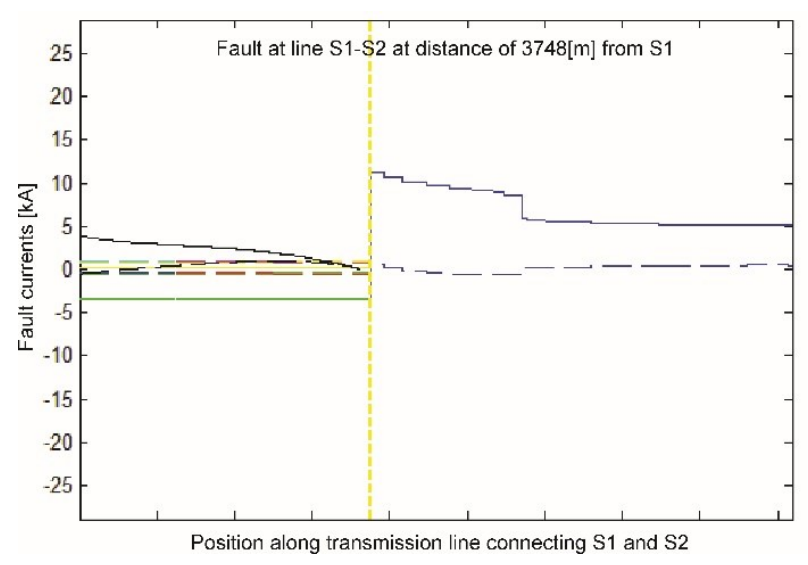

Fig. 8. Fault current distribution in elements of the electric power system (full line - real value, dashed line - imaginary value)

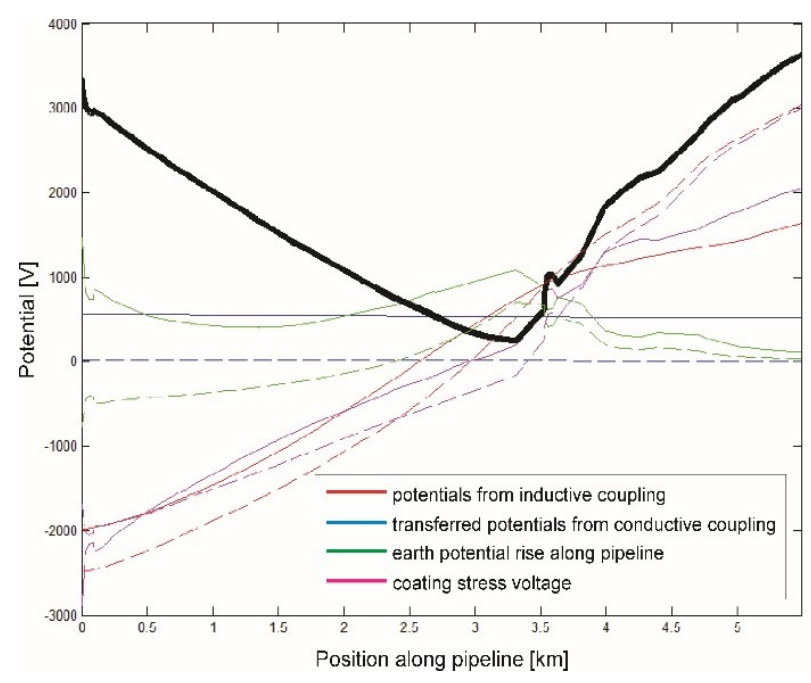

Fig. 9. Distribution of induced potentials along pipeline (full line - real value, dashed line - imaginary value)

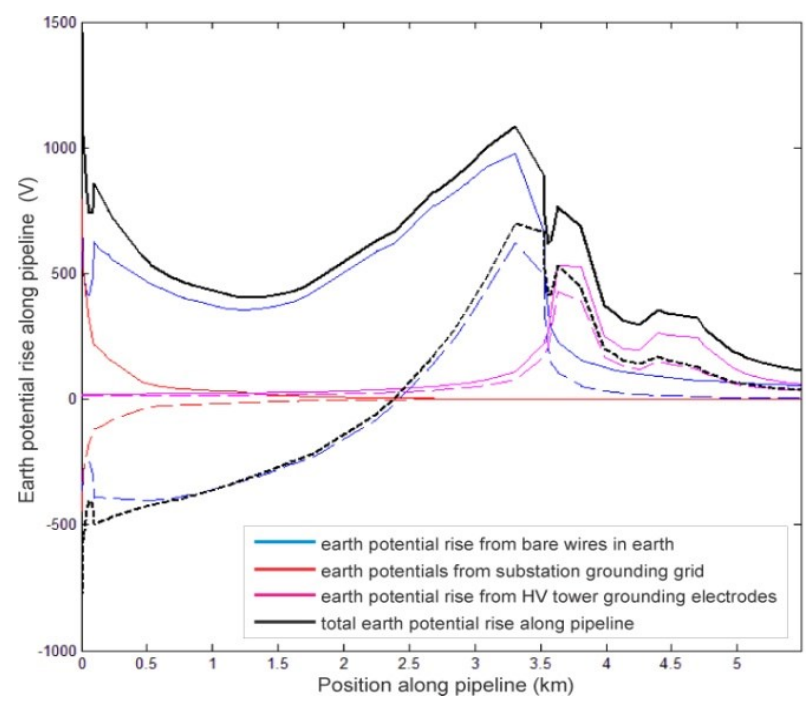

Fig. 10. Potentials from grounded structures of the electric power system (full line - real value, dashed line - imaginary value)

\section{RESULTS FROM THE SECOND \\ INTERVENTION - REDUCTION OF THE INDUCTIVE COUPLING}

Extensive analyses have shown that reduction of the induced voltages within safe levels can be achieved by splitting the pipeline in two electrically insulated sections using monolithic insulating joint and use of gradient control wires at the second section of the pipeline that is subject of inductive coupling from the overhead lines. To achieve optimal results, the second section of the pipeline should be grounded to these gradient control wires at every $300 \mathrm{~m}$ through DC decoupling devices. Positions of the applied protection are illustrated on Figure 11, and the achieved results are illustrated on Figures 12 to 15 .

Additional simpler interventions, like use of improved coating on the pipeline and use of additional protection of electrical equipment, at the short sections where induced voltages slightly exceed $2 \mathrm{kV}$, should satisfy the safety requirements for the pipeline and the connected equipment.

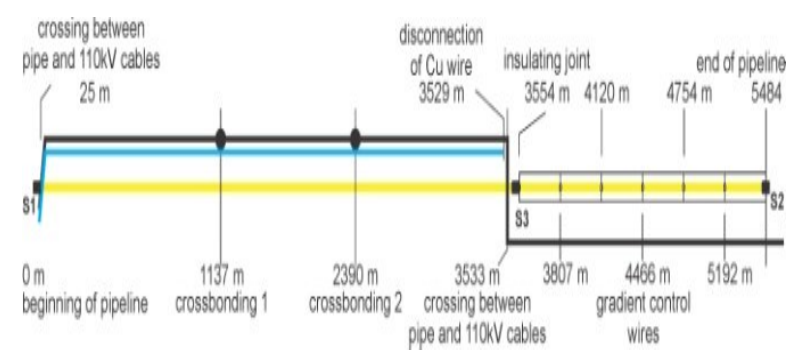

Fig. 11. Positions of applied protection measures after the second intervention

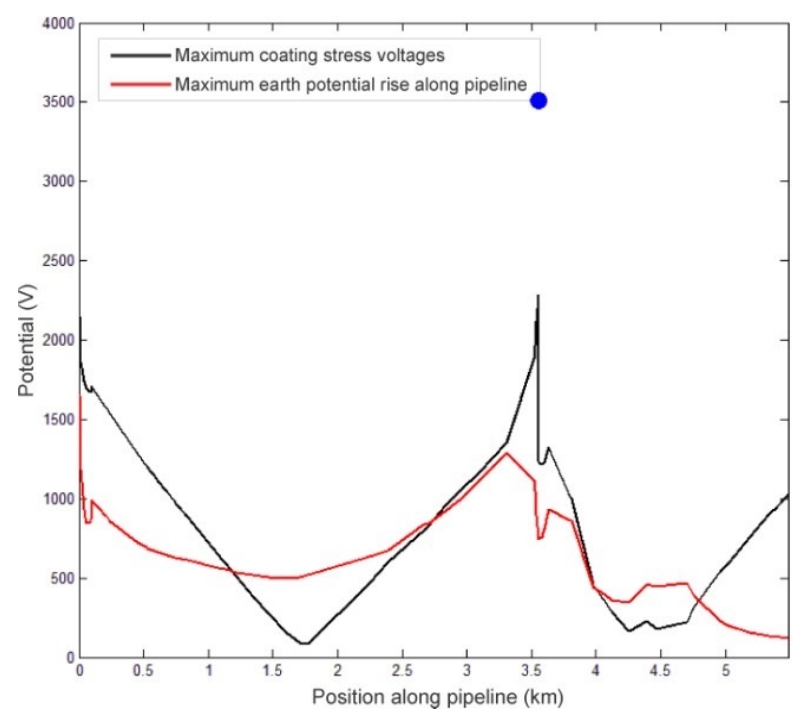

Fig. 12. Maximum coating stress voltage and ground potential rise after the second intervention 


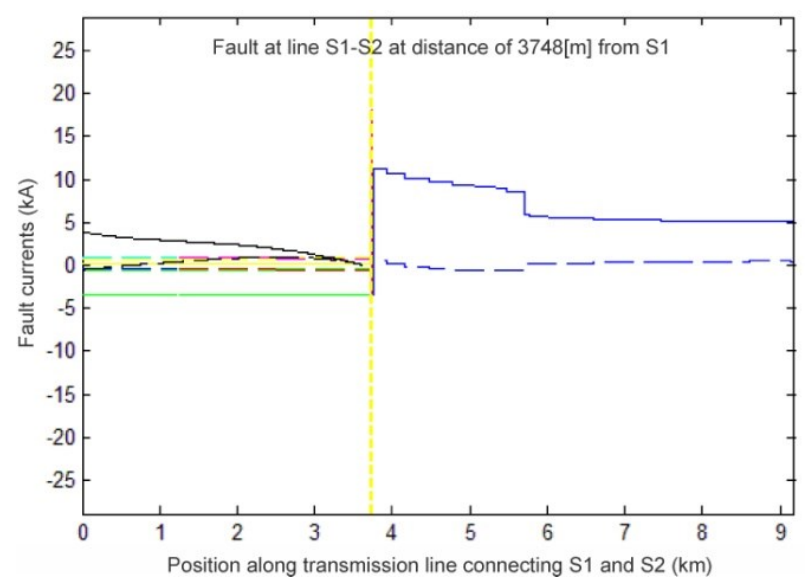

Fig. 13. Fault current distribution in elements of the electric power system

(full line - real value, dashed line - imaginary value)

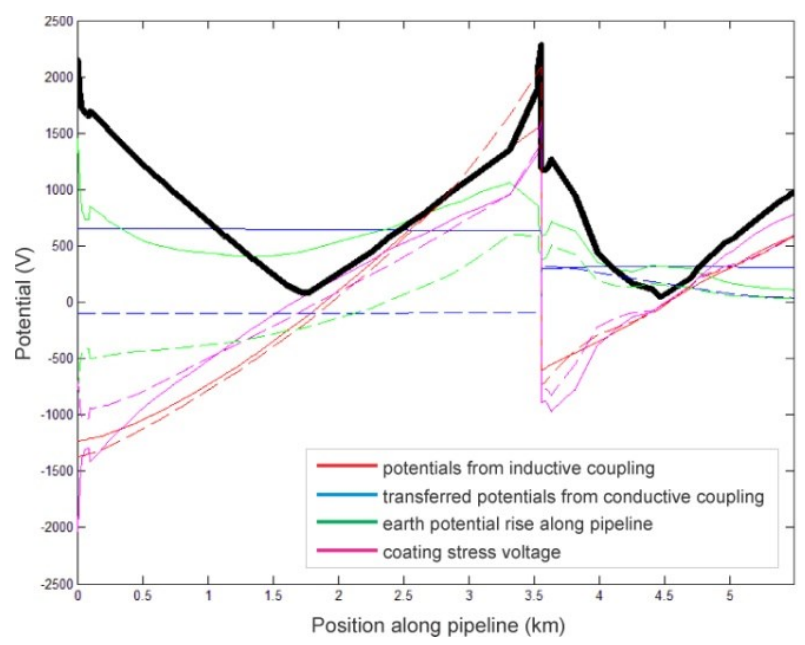

Fig. 14. Distribution of induced potentials along pipeline (full line - real value, dashed line - imaginary value)

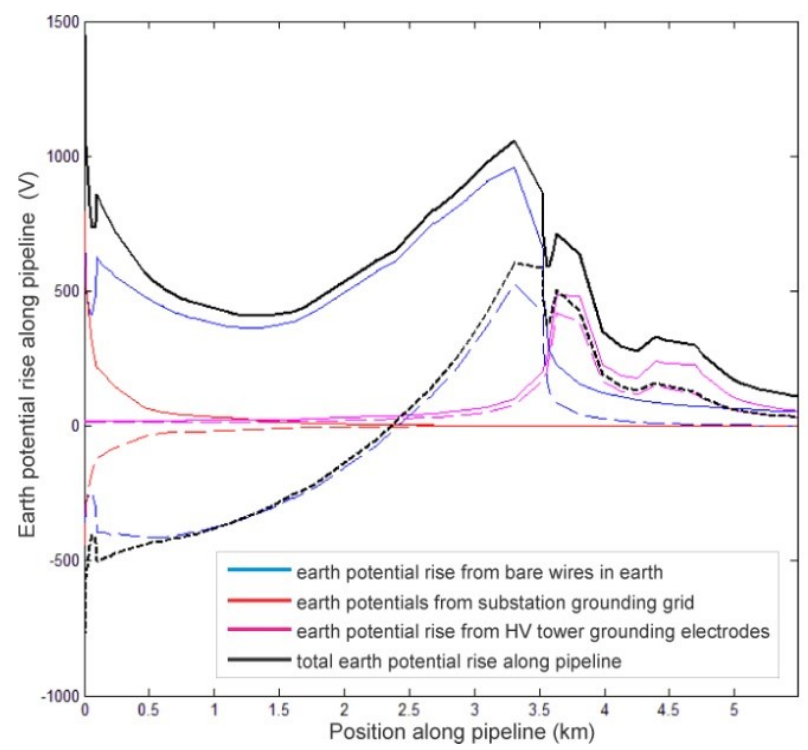

Fig. 15. Potentials from grounded structures of the electric power system

(full line - real value, dashed line - imaginary value)

\section{CONCLUSION}

Simulations are performed for electromagnetic influences between elements of power system and buried steel pipeline. Analysis is based on practical case, with existing transmission lines and construction project for the pipeline in preparation. The pipeline is subject to strong simultaneous inductive and conductive coupling with several elements and transmission lines of the power system, that result with induction of high voltages on the pipeline that well exceed the safety levels and may damage the coating and the connected equipment. Results from the analysis provide detailed insight into contributions to the induced voltages from different sources and may provide guidance in their reduction. By extensive analysis that consider all sources of influence, different fault positions and the impact from interventions in both systems, reduction of the induced voltages within safe levels has been achieved.

The goal of this paper is to emphasize the complex nature of the electromagnetic influences between power and pipeline systems, and the importance of this analysis as basis for their further design and construction. Protection from electromagnetic influences is one segment of the overall protection of the pipeline and must comply with the other protection systems, such as cathodic or lightning protection.

\section{REFERENCES}

[1] Guide on the Influence of High Voltage AC Power Systems on Metallic Pipelines. Paris, CIGRE Working Group 36. 02, 1995.

[2] Directives Concerning the Protection of Telecommunication Lines against Harmful Effects from Electric Power and Electrified Railway Systems. Volume II: Calculating Induced Voltages and Currents in Practical Cases, Geneva, CCITT, 1989.

[3] Guide for Assessment of Transferred EPR on Telecommunication Systems Due to Faults in A.C. Power Systems. Paris, CIGRÉ Working Group C4. 207, 2014.

[4] Sunde. E. D.: Earth Conduction Effects in Transmission Systems. New York: Dover, 1968.

[5] Wait, J. R.: Theory of Wave Propagation along a Thin Wire Parallel to an Interface. Radio Science. Vol. 7. pp. 675-679 (1972).

[6] Directives Concerning the Protection of Telecommunication Lines against Harmful Effects from Electric Power and Electrified Railway Systems, Volume III, Capacitive, Inductive and Conductive Coupling: Physical theory and calculation methods, Geneva, CCITT, 1989.

[7] Grčev, L., Dawalibi, F.: An Electromagnetic Model for Transients in Grounding Systems. IEEE Trans. on Power Delivery. Vol. 5. pp. 1733-1781 (1990). 
[8] Smith, A. A.: Coupling of External Electromagnetic Fields to Transmission Lines. New York: Wiley, 1977.

[9] МKC EN 50443:2012 - Effects of Electromagnetic Interference on Pipelines Caused by High Voltage A.C. Electric Traction Systems and/or High Voltage A.C. Power Supply Systems, Brussels: CENELEC, 2011.

[10] NACE SP0177-2014 - Mitigation of Alternating Current and Lightning Effects on Metallic Structures and Corroion
Control Systems. Houston, Texas: NACE International, 2014.

[11] Mangionem, S.: Compact Model of a Combined Overhead-Cable Line for Ground Fault Application Transfer Analysis, Proc. of the $5^{\text {th }}$ WHEAS Int. Conf. on Power Systems and Electromagnetic Compatibility. August 2325, 2005, pp. 251-256. 